\title{
Time travelling through local ecological knowledge regarding an endangered species
}

\author{
Ronaldo Sousa $^{\mathrm{a}, *}$, Joana Garrido Nogueira ${ }^{\mathrm{b}}$, Fernando Miranda ${ }^{\mathrm{c}}$, Amílcar Teixeira $^{\mathrm{c}}$ \\ a CBMA - Centre of Molecular and Environmental Biology, Department of Biology, University of Minho, Campus Gualtar, 4710-057 Braga, Portugal

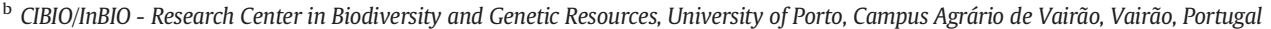 \\ c Centro de Investigação de Montanha (CIMO), Instituto Politécnico de Bragança, Campus de Santa Apolónia, 5300-253 Bragança, Portugal
}

\section{H I G H L I G H T S}

- We combine LEK and field sampling to assess the conservation status of M. margaritifera.

- In Cávado River the species is possibly extinct but respondents confirm its presence in the past.

- In Neiva River the species is still present but few respondents remembered its presence in the past.

- LEK is a low cost tool to get information about historical ecological conditions.

- Results reinforce concern about the future conservation of $M$. margaritifera in Portugal.

\section{A R T I C L E I N F O}

\section{Article history:}

Received 29 March 2020

Received in revised form 13 May 2020

Accepted 5 June 2020

Available online 6 June 2020

Editor: Sergi Sabater

\section{Keywords:}

Conservation

Freshwater ecosystems

Freshwater mussels

Questionnaires

Cávado and Neiva Rivers
GR A P H I C A L A B S T R A C T

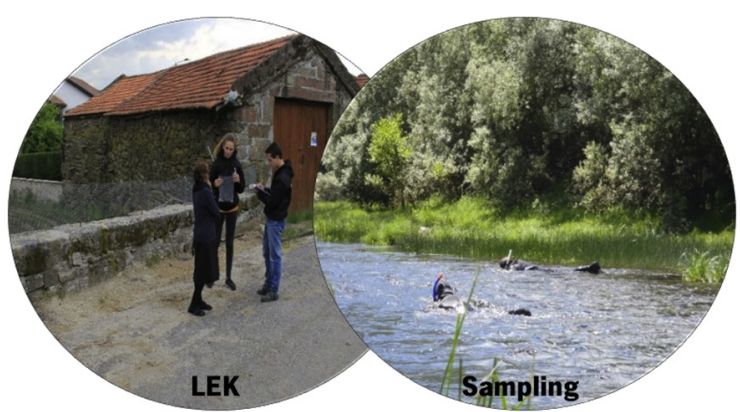

Conservation Assessment

\begin{abstract}
A B S T R A C T
European freshwater pearl mussel (Margaritifera margaritifera) populations are declining despite a growing effort to conserve them. Here we used a combination of local ecological knowledge (LEK) and field sampling to assess past and current distribution and conservation status of this endangered species in Cávado and Neiva Rivers (Portugal). We performed face-to-face interviews in both rivers and sampled the entire area where the respondents confirmed the historical presence of this species. Abiotic characterization, water quality and fish diversity were also assessed in both rivers. We found that freshwater pearl mussels are now possibly extinct in Cávado River but almost $50 \%$ of the respondents confirm its presence in the past, especially elders that lived in villages near its historical distribution. To the contrary, and although the species is still present in Neiva River, only $3.8 \%$ of the respondents remembered its presence in the past. In both rivers, respondents suggested pollution as the most important explanation for the freshwater pearl mussels decline. However, nowadays both rivers present excellent water quality and trout Salmo trutta (the freshwater pearl mussel fish host) is still abundant. Since we identified the areas where the species was present in a recent past, this information is vital for possible management actions with the aim of re-introduce or increase the abundance of M. margaritifera populations and/ or for the rehabilitation of habitats in both rivers. We also highlight the vital importance of getting LEK, mainly from elders, in order to avoid shifting baseline syndromes and to get qualitative accurate information of past references and/or experience with historical conditions. Results reported here reinforce concern about the conservation status of freshwater pearl mussel populations in Portugal and can be used to guide future research and management initiatives to better conserve this species.
\end{abstract}

(C) 2020 Elsevier B.V. All rights reserved.

\footnotetext{
* Corresponding author.

E-mail address: rg.eco.sousa@gmail.com (R. Sousa).
} 


\section{Introduction}

Several shortfalls can impair a comprehensive knowledge about biodiversity, including gaps in: taxonomy (Linnean shortfall), distribution (Wallacean shortfall), abundance and population dynamics (Prestonian shortfall), evolution (Darwinean shortfall), abiotic tolerances (Hutchinsonian shortfall), traits (Raunkiaeran shortfall) and biotic interactions (Eltonian shortfall) (Hortal et al., 2015). Given the increasing human disturbance on natural ecosystems, these shortfalls can limit ongoing and future biodiversity assessments and the application of management measures. As so, there is a great need to overcome these shortfalls, particularly in threatened species of less studied taxonomic groups such as freshwater mussels (Bivalvia, Unionida).

The freshwater pearl mussel Margaritifera margaritifera (Linnaeus, 1758 ) is listed as Critically Endangered in Europe by the IUCN (Moorkens et al., 2017). This bivalve has its taxonomy and evolution well studied (Lopes-Lima et al., 2018) as well as its abiotic tolerances (Varandas et al., 2013). Particular ecological traits and biotic interactions in M. margaritifera are well known since a significant amount of knowledge exists about their peculiar life cycle (i.e. the larva, glochidia, need a fish host to metamorphose into juveniles; Hastie and Young, 2001, 2003). Regarding distribution, abundance and population dynamics it is known that this species was once one of the most abundant and widespread aquatic invertebrates in the Holarctic, distributed from the artic and temperate regions of western Russia to the south-western Europe (Iberian Peninsula) and also the east coast of North America (North of USA and Canada) (Geist, 2010). In fact, freshwater pearl mussels were possibly so abundant that past reports described the species covering the stream bottom in several layers (Israel, 1913 in Geist, 2010). However, in the last 100 years the species declined more than $90 \%$, and even went extinct in some countries (Geist, 2010; LopesLima et al., 2017).

Although information about distribution at larger spatial scale do exist, the problem is that for most populations there is no historical data on abundance and population dynamics of M. margaritifera. This situation is problematic because it may impair the implementation of effective conservation measures by overlooking the distribution and abundance of historical and possibly more pristine conditions. In addition, declines in biodiversity can modify people's perceptions and according to Soga and Gaston (2018) without past references and/or experience with historical conditions, each new generation accepts the situation in which they are raised as being normal. This sociological and psychological phenomenon was coined by Pauly (1995) as the shifting baseline syndrome, when addressing the changes in fisheries and how fishers and scientists tend to perceive fish stocks at the beginning of their careers as the unaffected baseline condition. Therefore, a species that was widespread and very abundant in the past, such as M. margaritifera, may have experienced a large decline, but most current researchers, stakeholders and citizens can incorrectly presume that the population status in recent years is the appropriate baseline. Consequently, and to estimate long-term changes in populations distribution and abundance, researchers must rely either on past evidence from naturalist's records or use fossils and sub-fossils to determine historical distribution (see Popejoy et al., 2018a for an example on freshwater mussels). The problem with the historical data based on naturalist's records or based on fossils and sub-fossils is that they are rarely available in the form of quantitative data, including for invertebrate species such as bivalves (Alleway and Connell, 2015; Popejoy et al., 2018b). One way to overcome this lack of past information is the assessment of local ecological knowledge (LEK) held by citizens, especially elders (Johannes, 1998; Berkes et al., 2000, 2008). In fact, the verbal accounts of people that live in close proximity with nature may be a useful low-cost tool to reconstruct specific population's trends (Anadón et al., 2009; Brook and McLachlan, 2008; Turvey et al., 2010; Ziembicki et al., 2013). Therefore, and in the absence of standard ecological data about past distribution and abundance or the lack of historical archival documents, local respondents can provide important information about various ecological aspects (e.g. Turvey et al., 2014; Pan et al., 2016).

Given this context, and at least for a small temporal framework (decades), the use of interviews can be an excellent source of information to assess people's perception about the historical and current distribution, abundance trends and main threats to a given species (Anadón et al., 2009; Lozano-Montes et al., 2008; Dolrenry et al., 2016; Van et al., 2020; Camino et al., 2020). This kind of information can be complemented by written narratives and photographs, and have been quite used in terrestrial and marine ecosystems (Brook and McLachlan, 2008). Examples include assessments of stock declines of important fisheries or species of high conservation concern such as whales and turtles, as well as to identify reference conditions for habitat restoration, among other possibilities (McClenachan et al., 2012). However, very limited attempts were done in freshwater ecosystems and the few available are highly biased towards vertebrates (mainly fish) and we are not aware of the use of LEK to assess freshwater mussel population trends. In this study, we used LEK to reconstruct $M$. margaritifera population trends in Cávado and Neiva Rivers (Portugal). Information obtained was cross-validated with a survey to assess current distribution and abundance of freshwater pearl mussel populations, the presence of fish hosts as well as to evaluate the water quality using macroinvertebrates. Overall, information gathered can be used in future management actions devoted to the conservation of both populations.

\section{Material and methods}

\subsection{Study area}

The study area comprises part of the Cávado and Neiva Rivers, North of Portugal. Both rivers are located in the Minho region that is characterized by an irregular terrain, with elevations that can reach approximately $1500 \mathrm{~m}$, and by a compact valley system with a predominance of deep granitic soils. The climate in both river basins reflects the proximity to the Atlantic Ocean and the region is exposed to high maritime winds, high annual precipitations (1200-2400 $\mathrm{mm}$ ) and mild summers with summer mean temperatures ranging from 18 to $22^{\circ} \mathrm{C}$ (Fraga et al., 2014). River discharges in both rivers have high seasonal and interannual variation in response to precipitation with maximum values in winter/early spring and a subsequent reduction during summer/early autumn, when it reaches the lowest levels.

The Cávado River has a length of $135 \mathrm{~km}$ with its spring located in the Larouco Mountain in Montalegre and its mouth in Esposende. The Cávado basin covers an area of $1600 \mathrm{~km}^{2}$, being Homem and Rabagão Rivers the main tributaries. The study area has an extension of $25 \mathrm{~km}$, from Cabril to Montalegre villages. There are three dams (Salamonde, Paradela and Alto Cávado) in the study area constructed for the production of energy. The Neiva River has a length of $45 \mathrm{~km}$, and is located between the Lima (north) and Cávado River (south) basins. The Neiva basin covers a total area of $242 \mathrm{~km}^{2}$ and this river has its spring in the Oural Mountain and its mouth in Castelo do Neiva. There are no dams along the river, but many old weirs are present.

The river margins in both basins present riparian species like alder (Alnus glutinosa) and ash (Fraxinus angustifolia) trees. Among several aquatic species, we can find endemic cyprinids such as the Iberian barbel (Luciobarbus bocagei), Northern straight-mouth nase (Pseudochondrostoma duriense) and Northern Iberian chub (Squalius carolitertii). Regarding the main human activities, both basins have extensive agricultural and forestry areas and minimal industrial development. Even so, the study area in the Cávado River comprises less human disturbed habitats with a mix of primary and secondary forests as well as pasture and croplands located in the border of the Gerês National Park. In the Neiva River, the study area is more anthropogenically degraded and with less forest cover. In the study areas, human population density is of 14 and $174 \mathrm{ind} . / \mathrm{km}^{2}$ in Cávado and Neiva Rivers, respectively. 


\subsection{Local ecological knowledge surveys}

Since freshwater pearl mussel surveys covering the entire Portuguese distribution only started in 2000 and given the long life cycle of this species (more than 60 years; Sousa et al., 2015), the existing data set is insufficient to establish any long-term pattern. In order to surpass this caveat, face-to-face interviews using a questionnaire to collect information about $M$. margaritifera historical and current conservation status was designed (see Supplementary Material). We used face-to-face interviews as they are usually described to be more authentic and to obtain more direct answers (Rubin and Rubin, 2005). In addition, face-to-face interviews were the easiest way to target the elders in the study area since other alternatives (postal, telephone, internet) would probably miss this key target group (White et al., 2005). The questionnaire follows a simple layout with most questions in the closedformat requiring simple answers in order to reduce uncertainty (White et al., 2005) and was structured in two parts: 1) social characterization of the respondents, including demographic, social, and educational main features, and 2) information on freshwater pearl mussel conservation, including past and present distribution, the importance of its conservation, main threats to its survival and perceptions or attitudes towards conservation actions that may halt the species decline. Questions about fish species, especially brown trout $S$. trutta, were also asked given its importance for freshwater pearl mussel conservation. A pilot survey was performed using undergraduate students and university technicians to train the volunteers/researchers that will be involved in the collection of data, test the simplicity of the questions and to reduce potential problems caused by misunderstandings of the questionnaire. Interviews were performed during May 2019 by four persons (two undergraduate students and two researchers) and conducted in Cávado and Neiva Rivers proximal villages, in a maximum distance of $2 \mathrm{~km}$ from the river banks, where people were randomly chosen to participate. In Cávado River, interviews were conducted in 13 small villages located in both river banks from Cabril to Montalegre $(25 \mathrm{~km})$. In Neiva River interviews were conducted in 11 small villages located in both river banks from Forjães to Alheira $(20 \mathrm{~km})$. The duration of a single interview ranged between 15 and $20 \mathrm{~min}$ and after the social characterization we showed the respondents a shell of a $M$. margaritifera for better identification of the target species in question. It should be noted that in the study areas there are no records of other freshwater mussel species in historical or current times (Nobre, 1941; Reis, 2003; Sousa et al., 2015). All respondents were informed about the study general aim (collecting data to understand the ecological status of freshwater biodiversity) and were assured that data would be anonymized; interviews were conducted only after the participants gave verbal consent. Data collected in the survey was analysed using general descriptive statistics. We also performed a generalized linear model (GLM) using binomial distribution in $\mathrm{R}$ software ( $R$ Development Core Team) where age and location were used to assess a possible influence on the perception of each respondent on the historical presence of $M$. margaritifera in Cávado River. The variable location was treated as categorical (binary), considering a historical presence/absence of the species. This statistical analysis was not possible to perform in Neiva River as only four respondents confirm the historical (and current) presence of this species (see Results section).

In addition to the LEK assessment, and in order to evaluate possible distribution and abundance trends, we also used data available in Reis (2003) comprising samplings in 2001 and 2002 and Sousa et al. (2015) comprising samplings during August 2011.

A map containing the information about past and current (see below) distribution of $M$. margaritifera in Cávado and Neiva Rivers was developed in QGIS 2.18.26.

\subsection{Field surveys}

In June and July 2019 we re-sample both rivers to assess the current M. margaritifera distribution. These surveys were performed by snorkelling by two experienced divers covering the entire area where the respondents from the interviews (see above) confirm the historical presence of this species. In these surveys, both divers sampled the entire river sections continuously and only stretches in the Cávado River subjected to reservoirs influence were not surveyed. Freshwater pearl mussel individuals found in the Neiva River (see Results) were counted and measured with a Vernier calliper $(0.1 \mathrm{~mm})$ following the methodology described in Sousa et al. (2020).

Abiotic data, macroinvertebrates and fish communities were assessed in two sites in each river in May 2019. Information about water temperature, $\mathrm{pH}$, conductivity and dissolved oxygen was collected using a multi-parameter probe (YSI EXO2). Macroinvertebrates were sampled using a hand net with a mesh of $0.05 \mathrm{~cm}$ and a mouth width of $25 \mathrm{~cm}$. Each site corresponded to a river stretch with a total length of $50 \mathrm{~m}$ and the sampling covered all type of habitats (e.g. lentic and lotic, banks and centre of the channel, macrophytes) and sediments (e.g. pebbles, cobbles, sand, silt, clay). In each site, 6 replicates were performed with $1 \mathrm{~m}$ long and $0.25 \mathrm{~m}$ wide. The sampling net was placed counter-current while the substratum was moved, pushing the macroinvertebrates into the net. Organisms were stored and preserved (ethanol 70\%) in the field to be later sorted and identified to the family level (following Tachet et al., 2003). With this information, water quality indices were determined, including the IBMWP (Iberian Biological Monitoring Working Party) (Alba-Tercedor and Sánchez-Ortega, 1988), the IASPT (Iberian Average Score Per Taxa) and the \%EPT (percentage of Ephemeroptera, Plecoptera and Tricoptera families). Fish fauna was surveyed by electrofishing using a portable equipment Hans Grassl ELT60II with a pulsed DC-300-600 V generator in the same four selected sites. Sites had a total length of $100 \mathrm{~m}$ and electrofishing was performed in all type of habitats and sediments (as described above). Fisheries lasted $20 \mathrm{~min}$ and were performed by three experienced researchers. The stunned fish were collected and posteriorly identified to the species level, counted and measured with a ruler. All specimens were released after these measurements. Fish abundance was expressed as the number of individuals in a 20-minute fishery - individuals per catch per unit effort (ind. CPUE).

\section{Results}

\subsection{Local ecological knowledge surveys}

A total of 200 persons responded the questionnaires, being 96 in Cávado and 104 in Neiva and a general social characterization of respondents is presented in Table 1 . All respondents had a very positive attitude answering all questions during the interview. A percentage of $46.3 \%$ of the respondents in Cávado River remembered the presence of M. margaritifera in the past. As for Neiva River, only 4 (3.8\%) respondents remembered its presence. A significant influence of the age of respondents $(\mathrm{p}=.001)$ and location $(\mathrm{p}=.001)$ concerning the presence of $M$. margaritifera in Cávado River was detected. Average age of respondents that recognized the presence of this species was higher and live nearer to $M$. margaritifera historical occurrence and there was no significant interaction between age and location $(p=.291)$. None of the respondents knew that freshwater pearl mussels are protected by law.

A very high percentage of respondents in both rivers have a very positive attitude to the importance of $M$. margaritifera conservation (89.6\% in Cávado River, Fig. 1A; and 90.4\% in Neiva River, Fig. 1B), being that $7.3 \%$ and $1.9 \%$ of the respondents did not had an opinion. A total of $97.9 \%$ and $89.4 \%$ of the respondents agreed that local municipalities and/or national government should spend money on M. margaritifera conservation, against $2.1 \%$ and $9.7 \%$ that disagree with this possibility in Cávado and Neiva Rivers, respectively (Fig. 1A and 
Table 1

General social characterization of the respondents to the questionnaire.

\begin{tabular}{lll}
\hline & Cávado (\%) & Neiva (\%) \\
\hline Gender & 55.2 & \\
Male & 44.8 & 71.2 \\
Female & & 28.8 \\
Age & 1.1 & \\
$0-20$ & 5.2 & 3.8 \\
$21-40$ & 32.3 & 17.3 \\
$41-60$ & 45.8 & 35.6 \\
$61-80$ & 15.6 & 33.7 \\
$81-93$ & & 9.6 \\
Education & 62.5 & \\
Primary school level & 21.9 & 39.5 \\
Middle school level & 3.1 & 31.7 \\
High school level & 2.1 & 23.1 \\
College level & 10.4 & 3.8 \\
Without & & 1.9 \\
\hline
\end{tabular}

B). In addition, $90.6 \%$ of the respondents in Cávado (Fig. $1 \mathrm{~A}$ ) and $65.4 \%$ in Neiva (Fig. 1B) Rivers are willing to help (financially and/or doing some volunteering work) freshwater pearl mussel's conservation. When asked for the reason of the species decline, $91.7 \%$ and $75.0 \%$ of the respondents referred water pollution as the main cause in Cávado and Neiva Rivers, respectively. Other respondents referred the construction of dams in Cávado River (8.3. \%) and 25.0\% in the Neiva River did not
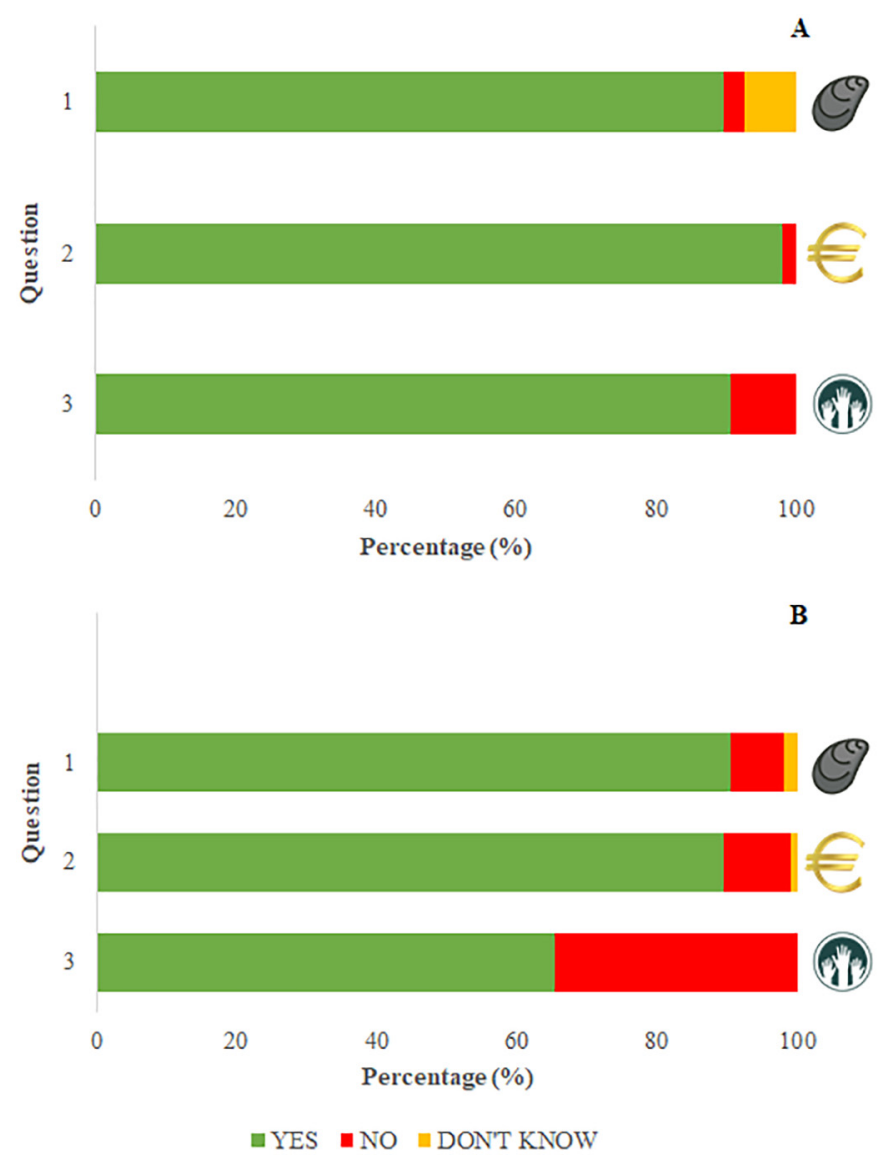

Fig. 1. Percentage of answers given by the respondents to the question: 1: 'Do you think that the conservation of Margaritifera margaritifera is important?; 2: 'Do you agree that local municipalities and/or national government spend money on Margaritifera margaritifera conservation?' and 3: 'Would you be willing to help (financially and/or doing some volunteering work) to conserve Margaritifera margaritifera?' in Cávado (A) and Neiva (B) Rivers. advance with any possibility. When asked for the main reason to conserve freshwater pearl mussels, most respondents mentioned the intrinsic value of nature conservation given that $M$. margaritifera is a native and rare species (56.8\% in Cávado and $76.0 \%$ in Neiva Rivers; Fig. 2A). In addition, respondents (20.6\% in Cávado and 7.6\% in Neiva) also mention the importance of the species providing some ecosystem services (resource as food, filtration, and cultural and tourism importance; Fig. 2A). Regarding the solutions to halt M. margaritifera decline, most people consider the control of pollution to be the best option (49.2\% and $50.0 \%$ of the responses in Cávado and Neiva Rivers, respectively) next to the increase of awareness (27.8\% and $18.6 \%$ in Cávado and Neiva Rivers, respectively) (Fig. 2B).

\subsection{Field surveys}

Abiotic characterization in each study site is presented in Table 2.

The distribution of $M$. margaritifera suffered a decline in Cávado River in the recent decades (Fig. 3A). Last records of the presence of individuals are from 2001 (3 individuals found; Reis, 2003) and after this date, and despite surveys in 2011 (Sousa et al., 2015) and in 2019 (this study), no freshwater pearl mussels or empty shells were recently found. In Neiva River, M. margaritifera also suffered a decline in terms of spatial distribution (Fig. 3B) and also in abundance. Indeed, in the survey made in 2011 (Sousa et al., 2015) a total of 21 individuals were found but in the 2019 only 4 individuals could be detected.

Regarding the macroinvertebrate communities, a total of 1337 and 1150 macroinvertebrates were sampled in Cávado and Neiva Rivers, respectively (Table 2). Macroinvertebrate abundance varied between 489 (N2) and 758 (C1) individuals and taxonomic richness (number of families) varied between 21 (C2) and 36 (N1) (Table 2). Water quality index IBMWP showed that all sites in Cávado and Neiva Rivers have excellent water quality since IBMWP values varied between 111 in C2 and

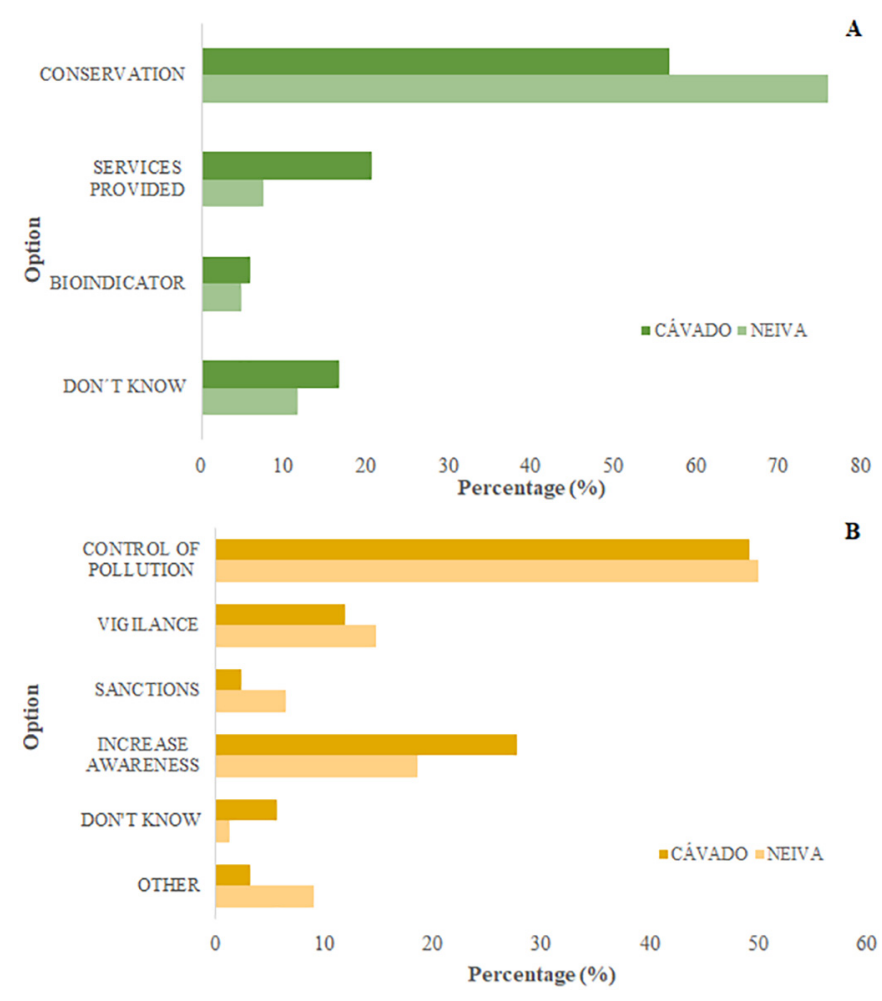

Fig. 2. Percentage of answers given by the respondents to the questions: 'Why do you think that the conservation of Margaritifera margaritifera is important?' (A) and 'What do you think that needs to be done to halt Margaritifera margaritifera decline?' (B). 
Table 2

Abiotic characterization, macroinvertebrate diversity, water quality and fish diversity in the sites sampled in Cávado (C1 and C2) and Neiva (N1 and N2) Rivers. N: Abundance; $\mathrm{S}$ : Taxa richness; $\mathrm{H}^{\prime}$ : Shannon-Wiener diversity index and $\mathrm{J}^{\prime}$ : Pielou equitability index.

\begin{tabular}{lllll}
\hline & $\mathrm{C} 1$ & $\mathrm{C} 2$ & $\mathrm{~N} 1$ & $\mathrm{~N} 2$ \\
\hline Abiotic characterization & & & & \\
$\mathrm{pH}$ & 7.17 & 7.48 & 7.13 & 7.67 \\
Temperature $\left({ }^{\circ} \mathrm{C}\right)$ & 13.05 & 12.40 & 14.90 & 14.80 \\
Conductivity $(\mu \mathrm{S} / \mathrm{cm})$ & 22.50 & 20.00 & 68.50 & 61.00 \\
Oxygen $(\mathrm{mg} / \mathrm{L})$ & 9.95 & 10.03 & 9.56 & 10.15 \\
Macroinvertebrates & & & & \\
$\mathrm{N}$ & 758 & 579 & 661 & 489 \\
$\mathrm{~S}$ & 23 & 21 & 36 & 29 \\
$\mathrm{H}$ & 1.16 & 1.88 & 1.94 & 2.38 \\
$\mathrm{~J}$ & 0.37 & 0.62 & 0.55 & 0.71 \\
Water quality & & & & \\
IBMWP & 130 & 111 & 217 & 157 \\
IASPT & 5.42 & 5.29 & 6.03 & 5.41 \\
EPT $(\%)$ & 41.70 & 38.10 & 50.00 & 44.80 \\
Fish & & & & \\
$\mathrm{N}$ & 57 & 11 & 169 & 131 \\
$\mathrm{~S}$ & 3 & 1 & 6 & 6 \\
$\mathrm{H}$ & 0.90 & 0.00 & 1.22 & 1.16 \\
$\mathrm{~J}$ & 0.82 & 0.00 & 0.68 & 1.22 \\
\hline
\end{tabular}

217 in N1 (Table 2). IASPT values ranged from 5.3 (C2) and 6.0 (N1) and EPT percentage varied between $38.1 \%$ in C2, and $50.0 \%$ in N1 (Table 2).

Regarding fish communities, we collected a total of 68 and 300 fishes in Cávado and Neiva Rivers, respectively (Table 2). Abundance varied between 11 (C2) and 169 (N1) ind. CPUE and taxonomic richness varied between 1 (C2) and 6 species in both sites of Neiva River (Table 2). Salmo trutta was present in all sites, varying between 7 (N1) and 13 (C1) ind. CPUE.

\section{Discussion}

In this study we used a combination of LEK and field surveys (Fig. 4) to reconstruct the historical and current distribution of two freshwater pearl mussel populations in the north of Portugal. To our knowledge this is the first study showing the usefulness of LEK for freshwater pearl mussel conservation in a systematic manner. Combining LEK and field surveys, we found that M. margaritifera was widespread (and possibly very abundant) in Cávado River a few decades ago but this population is possibly extinct nowadays. In Neiva River the species was already rare in the past and restricted to a small area but a few individuals still persist nowadays. This study emphasises the importance of LEK, mainly from elders, since it is a source of low-cost and high quality information to clarify the historical distribution of M. margaritifera.

\subsection{Socio-ecological assessment}

Respondents in both basins were proved as a fertile ground where to explore LEK on $M$. margaritifera. In most cases, respondents were glad to share information with researchers and some (mostly in Cávado basin) shared a feeling of joy and emotion when the freshwater pearl mussel shells were shown during the face-to-face interviews.

Even though freshwater pearl mussels were not found in current surveys in Cávado River, almost half the respondents confirm its presence at least until late 1990s. This information is in accordance with the sampling made by Reis (2003) that confirm the presence of the species in 2001 in the Cávado River, although only 3 individuals were found. Many respondents believe that the decline of freshwater pearl mussels was caused by organic pollution originated in the village of Montalegre (the first water treatment plant was only constructed in the 1980s). To the contrary, although the species is still present in the
Neiva River, only four respondents remembered and confirmed its presence in the past. This difference in both rivers could be related to the fact that the villages surrounding Cávado River are more rural with an ageing population, and people are more aware of wild species present in their area. In addition, it may happen that the abundance of M. margaritifera was always low in the past 4-5 decades in the Neiva River (contrary to Cávado River, where some respondents reported the presence of many individuals in some river stretches; for example, one respondent said that in the late 1960s it was possible to collect a 10 L bucket of freshwater pearl mussels in 20-30 min). The decrease of freshwater pearl mussels found in Neiva River, from 21 individuals in 2011 (Sousa et al., 2015) to 4 in 2019 (this study) is substantial and showed the continuous declining trend of this species in this river. Most of respondents attribute this decline to pollution mainly caused by agricultural activities.

Although respondents advance with pollution as the major cause of decline in both populations, the reality is that both rivers present, nowadays, an excellent water quality. In fact, water quality indices in both rivers are similar to values reported for the Rabaçal and Tuela Rivers (Nogueira, 2019) that contain the healthiest M. margaritifera populations in Portugal (Sousa et al., 2015, 2020). Also, the four sites surveyed were characterized by the presence of heterogeneous habitats (authors personal observation), hosting a large diversity of invertebrates and fishes, including the host fish species $S$. trutta.

Respondents believed that the conservation of $M$. margaritifera is important, mostly because it is a native and rare species. However, some people also referred the ecosystem services provided by this species, such as water purification, the possible use as a food resource, and the fact that the species may function as an indicator of excellent water quality. Even so, there is still little knowledge about the conservation status of freshwater invertebrates by the locals, being that none of the respondents knew that freshwater pearl mussels are protected by law, and this lack of knowledge can impair the implementation of future conservation actions.

A great difficulty faced by conservation is the lack of public support (Courchamp et al., 2018), and this situation is possibly much more acute in less charismatic endangered species such as aquatic invertebrates. Even so, the great majority of the respondents agree that the conservation of freshwater pearl mussels is important and support the idea that local or national government should spend financial resources in their protection. In addition, the majority of respondents support the idea of helping financially (or acting as volunteers) in the application of possible management measures for freshwater pearl mussel conservation. This situation follow other studies (e.g. Lindhjem and Tuan, 2012; Diffendorfer et al., 2014); however, most of these examples are focused on vertebrate or charismatic species and not on invertebrate aquatic species.

The importance of face-to-face interviews is obvious (e.g. assess habitat loss, assess population trends, identify main threats, design proper management measures) and can be easily used for the assessment of other aquatic species. In addition, these interviews confirm once more that although the presence and abundance of some species, including freshwater pearl mussels, of former times lives in the memories of elders, these memories did not pass to the younger generations, showing another example of people's disconnection (especially younger generations) from nature (see Soga and Gaston, 2016). This situation was obvious in the Cávado River. In reality, several times most of the younger respondents said that bivalves only exist at the sea and it will be impossible to find them so far away from the coast. The use of interviews illustrates that elders still have a rich heritage and their knowledge should not be ignored because it offers an important conservational perspective even in rare species such as the freshwater pearl mussel M. margaritifera. This knowledge may be key in facing today's challenges in the management of natural ecosystems (LozanoMontes et al., 2008). The shifting of ecological baselines and loss of knowledge between generations could be one of the most important 


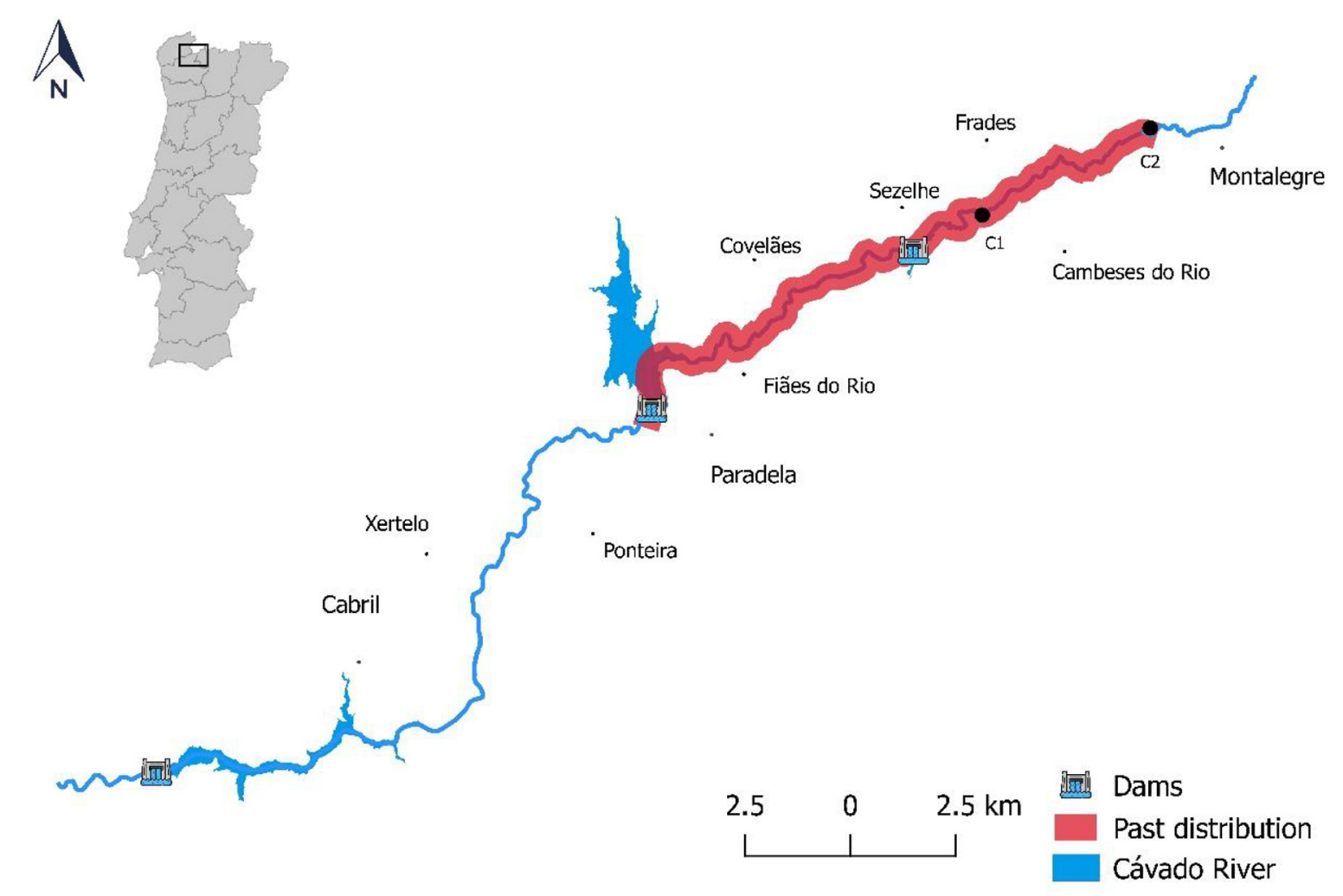

A

B

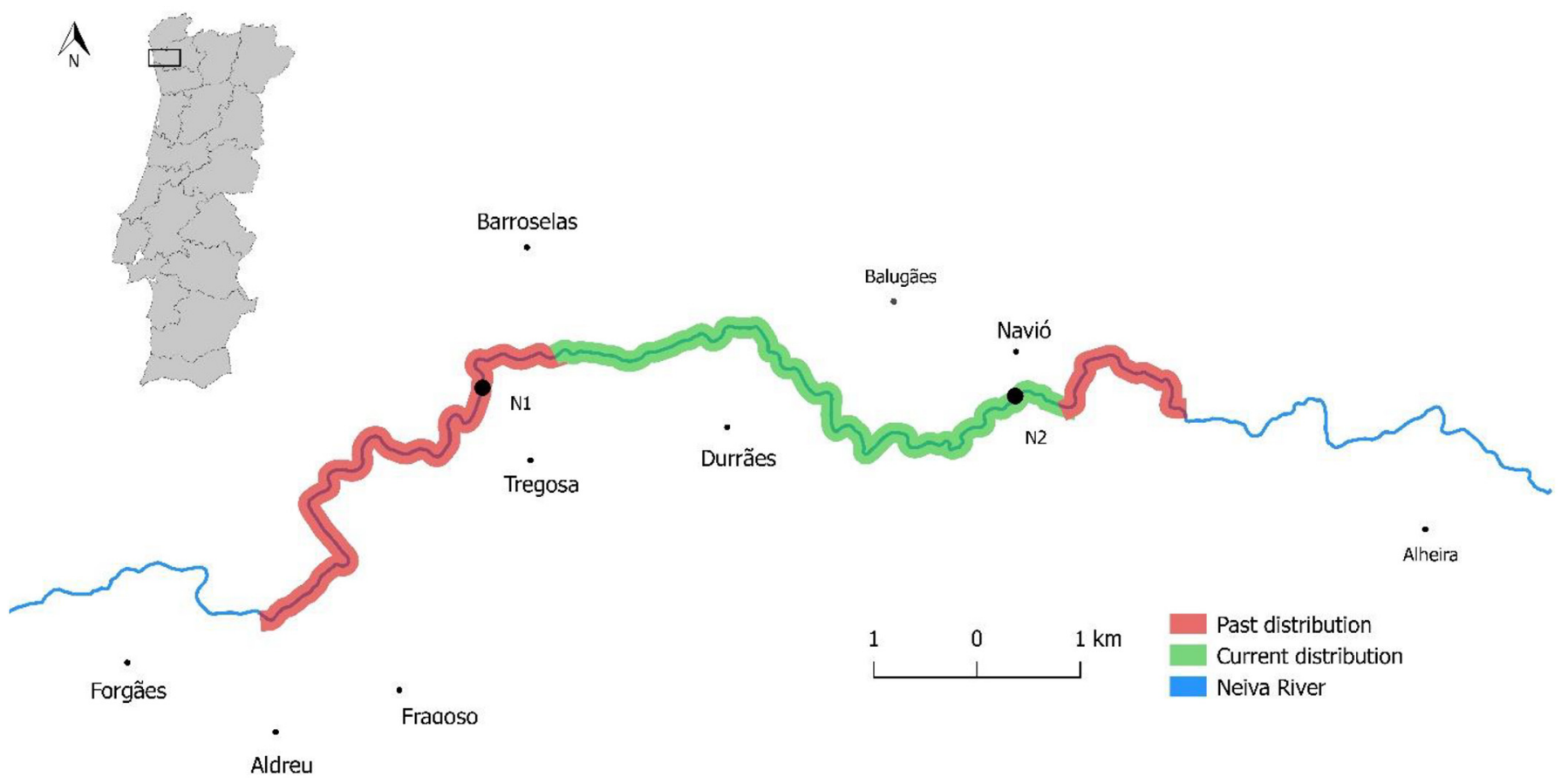

Fig. 3. Map of the surveyed areas in Cávado (A) and Neiva (B) Rivers showing past and current distribution of Margaritifera margaritifera.

reasons that our society tolerates loss of biodiversity and does not always appreciate the conservation efforts that must be taken in order to protect or restore ecosystems (Turvey et al., 2010). This may be even more acute in freshwater ecosystems and in invertebrate species, which are usually neglected in comparison with terrestrial vertebrate species (Clark and May, 2002; Ford et al., 2017). Therefore, is quite important that information still retained by elders can be transmitted to the younger generations and some measures should be applied in order to share this ancient knowledge (e.g. oral session of elders in schools, storytelling sessions, participatory theatre sessions, radio series and video documentaries; Heras and Tàbara, 2016; FernándezLlamazares and Cabeza, 2018). 

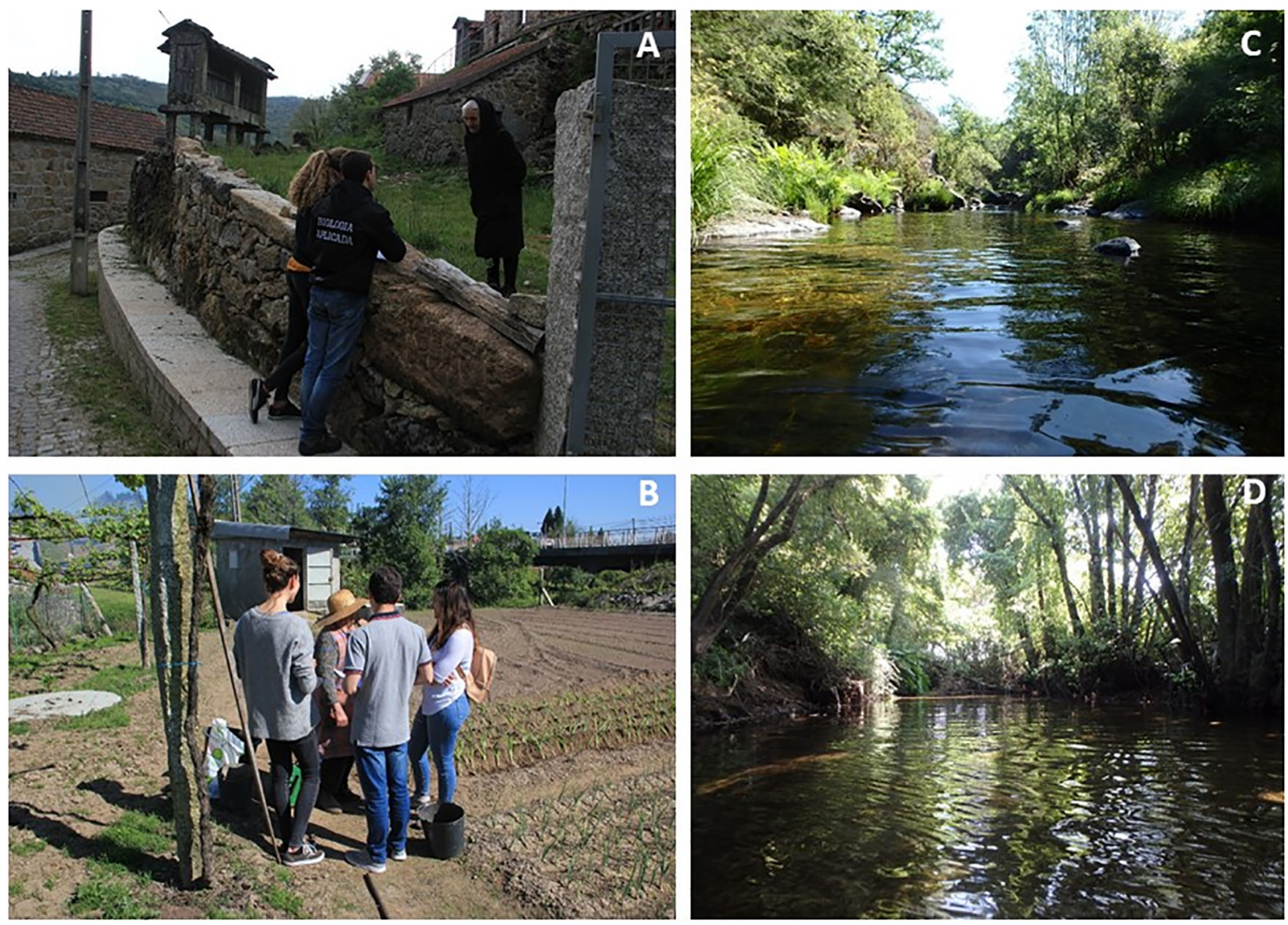

Fig. 4. Face-to-face interviews in Cávado (A) and Neiva (B) Rivers and typical surveyed river stretches in Cávado (C) and Neiva (D) Rivers.

Despite the obvious advantages of using LEK, several studies pointed out that information collected by questionnaires does not have the scientific validity of data collected directly by scientists and so there is always some uncertainty in the interpretations that can be made (White et al., 2005; Davis and Ruddle, 2010; Van et al., 2020). Also, it is widely known in this type of works that participants tend to answer in the way that they think the interviewers want to hear instead of what they really think or give exaggerated assessments of actual threats imposed by certain species or human activities (Turvey et al., 2014). Finally, bias can be also introduced due to variation in environmental awareness and perception between different socio-economic and cultural groups present across the study area (White et al., 2005; Davis and Ruddle, 2010). Overall, these limitations in our study should be minimal since respondents belong to a homogeneous socio-economic group with similar past or current labour activities mainly based in subsistence agriculture. In addition, we believe that respondents were not pre-dispose to answer 'correctly' since, for instance, most respondents in Neiva River did not recognize the species.

\subsection{Conservation implications}

Given the declines in distribution and abundance of $M$. margaritifera, the development of conservation plans to recover this species are urgently necessary. There are several actions that could be implemented to conserve and restore $M$. margaritifera populations in Cávado and Neiva Rivers, which include the creation of protected areas, restoration of aquatic habitats, transferring individuals from rivers with healthy populations, release infested fish hosts and cultivation and restocking of juveniles (Preston et al., 2007; Geist, 2010; Lopes-Lima et al., 2017). Given the excellent water quality and the presence of salmonid hosts, Cávado and Neiva Rivers could be considered for a possible program of releasing hatchery reared M. margaritifera. For Cávado River it would be considered a re-introduction in its formal natural habitat and source populations should come from the most geographically proximal populations, located in Beça River (Douro basin) or from Lima and Salas Rivers (Lima basin). As for Neiva River, a rehabilitation of an existing population by reproduction in captivity and posterior release and/or release of infested trout should be considered. The plans mentioned above should cover the historical known distribution of $M$. margaritifera and give a special attention to hydromorphological variables (see Zając et al., 2018).

\section{Conclusion}

In this study we confirm that the degree of knowledge of local inhabitants, especially elders, must be valued and the interplay between the ecological and social knowledge was able to identify the past and current distribution of a rare species. This was somehow unexpected since this kind of information provided by untrained observers is more common on charismatic and easily identifiable species, typically large bodied vertebrates (usually mammals or birds), and/or species with significant socio-economic or cultural importance (Jones et al., 2008; Turvey et al., 2014). In fact, this study showed that LEK can be also used in freshwater invertebrates and was possibly the unique way to assess historical distribution and get information of possible past and ongoing environmental changes in Cávado and Neiva Rivers. Therefore, we advocate the use of LEK as a standard low-cost tool for the sampling of aquatic species, including freshwater mussels, particularly when abundances are low and traditional sampling methods to assess past data may be impossible to apply or are very expensive to implement. Traditionally, ecology is based in the collection of factual information but there is a growing need do include stakeholders and general public perceptions in the conservation agenda because it will give a 
more holistic picture of the topic under survey and represents an opportunity for ecologists to get more involved in policy-oriented research (White et al., 2005). When possible, these LEK assessments should be complemented by field sampling to confirm main conclusions.

\section{CRediT authorship contribution statement}

Ronaldo Sousa:Methodology, Resources, Formal analysis, Writing original draft.Joana Garrido Nogueira:Resources, Formal analysis. Fernando Miranda:Resources.Amílcar Teixeira:Resources.

\section{Declaration of competing interest}

The authors declare that there is no conflict of interests in this work.

\section{Acknowledgments}

This work was supported by POSEUR-03-2215-FC-000096 and ICNF funds under project CP01-MARG-QUERCUS/2018. We acknowledge André Vinhas Fernandes, Bruna Gonçalves, Maria Inês Carvalho and José Vasco for the help in doing the interviews and field work. We thank Ivan Bolotov and two anonymous referees for the valuable suggestions made, which increased the clarity of our manuscript.

\section{Appendix A. Supplementary data}

Supplementary data to this article can be found online at https://doi. org/10.1016/j.scitotenv.2020.140047.

\section{References}

Alba-Tercedor, J., Sánchez-Ortega, A., 1988. Un método rápido y simple para evaluar la calidad biológica de las aguas corrientes basado en el de Hellawell (1978). Limnetica 4, 1-56.

Alleway, H.K., Connell, S.D., 2015. Loss of an ecological baseline through the eradication of oyster reefs from coastal ecosystems and human memory. Conserv. Biol. 29, 795-804.

Anadón, J.D., Giménez, A., Ballestar, R., Pérez, I., 2009. Evaluation of local ecological knowledge as a method for collecting extensive data on animal abundance. Conserv. Biol. 23, 617-625.

Berkes, F., Folke, C., Colding, J. (Eds.), 2000. Linking Social and Ecological Systems: Management Practices and Social Mechanisms for Building Resilience. Cambridge University Press.

Berkes, F., Colding, J., Folke, C. (Eds.), 2008. Navigating Social-Ecological Systems: Building Resilience for Complexity and Change. Cambridge University Press.

Brook, R.K., McLachlan, S.M., 2008. Trends and prospects for local knowledge in ecological and conservation research and monitoring. Biodivers. Conserv. 17, 3501-3512.

Camino, M., Thompson, J., Andrade, L., Cortez, S., Matteucci, S.D., Altrichter, M., 2020. Using local ecological knowledge to improve large terrestrial mammal surveys, build local capacity and increase conservation opportunities. Biol. Conserv. 244, 108450. https://doi.org/10.1016/j.biocon.2020.108450.

Clark, J.A., May, R.M., 2002. Taxonomic bias in conservation research. Science 297, 191-192.

Courchamp, F., Jaric, I., Albert, C., Meinard, Y., Ripple, W.J., Chapron, G., 2018. The paradoxical extinction of the most charismatic animals. PLoS Biol. 16.

Davis, A., Ruddle, K., 2010. Constructing confidence: rational skepticism and systematic enquiry in local ecological knowledge research. Ecol. Appl. 20, 880-894.

Diffendorfer, J.E., Loomis, J.B., Ries, L., Oberhauser, K., Lopez-Hoffman, L., Semmens, D., Semmens, B., Butterfield, B., Bagstad, K., Goldstein, J., Wiederholt, R., Mattsson, B., Thogmartin, W., 2014. National valuation of monarch butterflies indicates an untapped potential for incentive-based conservation. Conserv. Lett. 7, 253-262.

Dolrenry, S., Hazzah, L., Frank, L.G., 2016. Conservation and monitoring of a persecuted African lion population by Maasai warriors. Conserv. Biol. 30, 467-475.

Fernández-Llamazares, Á., Cabeza, M., 2018. Rediscovering the potential of indigenous storytelling for conservation practice. Conserv. Lett. 11, e12398.

Ford, A.T., Cooke, S.J., Goheen, J.R., Young, T.P., 2017. Conserving megafauna or sacrificing biodiversity? BioScience 67, 193-196.

Fraga, H., Malheiro, A.C., Moutinho-Pereira, J., Santos, J.A., 2014. Climate factors driving wine production in the Portuguese Minho region. Agric. For. Meteorol. 185, 26-36.

Geist, J., 2010. Strategies for the conservation of endangered freshwater pearl mussels (Margaritifera margaritifera L.): a synthesis of conservation genetics and ecology. Hydrobiologia 644, 69-88.

Hastie, L.C., Young, M.R., 2001. Freshwater pearl mussel (Margaritifera margaritifera) glochidiosis in wild and farmed salmonid stocks in Scotland. Hydrobiologia 445, 109-119.

Hastie, L.C., Young, M.R., 2003. Timing of spawning and glochidial release in Scottish freshwater pearl mussel (Margaritifera margaritifera) populations. Freshw. Biol. 48, 2107-2117.
Heras, M., Tàbara, D., 2016. Conservation theatre: mirroring experiences and performing stories in Community Management of Natural Resources. Soc. Nat. Resour. 29, 948-964.

Hortal, J., de Bello, F., Diniz-Filho, J.A.F., Lewinsohn, T.M., Lobo, J.M., Ladle, R.J., 2015. Seven shortfalls that beset large-scale knowledge of biodiversity. Annu. Rev. Ecol. Evol. Syst. 46, 523-549.

Johannes, R.E., 1998. The case for data-less marine resource management: examples from tropical nearshore fin fisheries. Trends in Ecology and Evolution 13, 243-246.

Jones, J.P.G., Andriamarovololona, M.M., Hockley, N., Gibbons, J.M., Milner-Gulland, E.J. 2008. Testing the use of interviews as a tool for monitoring trends in the harvesting of wild species. J. Appl. Ecol. 45, 1205-1212.

Lindhjem, H., Tuan, T.H., 2012. Valuation of species and nature conservation in Asia and Oceania: a meta-analysis. Environ. Econ. Policy Stud. 14, 1-22.

Lopes-Lima, M., Sousa, R., Geist, J., Aldridge, D.C., Araujo, R., Bergengren, J., Zogaris, S., 2017. Conservation status of freshwater mussels in Europe: state of the art and future challenges. Biol. Rev, 92, 572-607.

Lopes-Lima, M., Bolotov, I., Do, V.T., Aldridge, D., Fonseca, M., Gan, M.H., Gofarov, M.Y., Kondakov, A., Prié, V., Sousa, R., Varandas, S., Vikhrev, I., Teixeira, A., Wu, R.W., Wu, X., Zieritz, A., Froufe, E., Bogan, A., 2018. An expansion and systematics redifinition of the most threatened freshwater mussel family, the Margatiferidae. Mol. Phylogenet. Evol. 127, 98-118.

Lozano-Montes, H.M., Pitcher, T.J., Haggan, N., 2008. Shifting environmental and cognitive baselines in the upper Gulf of California. Front. Ecol. Environ. 6, 75-80.

McClenachan, L., Ferretti, F., Baum, J.K., 2012. From archives to conservation: why historical data are needed to set baselines for marine animals and ecosystems. Conserv. Lett. 5, 349-359.

Moorkens, E., Cordeiro, J., Seddon, M.B., von Proschwitz, T., Woolnough, D., 2017 Margaritifera margaritifera. The IUCN Red List of Threatened Species.

Nobre, A., 1941. Fauna malacológica de Portugal. Moluscos terrestres e fluviais. Memórias e Estudos do Museu Zoológico, Universidade de Coimbra, Coimbra (in Portuguese).

Nogueira, J.G., 2019. Freshwater Biodiversity Assessment in áreas with and without Protection. Master Thesis. University of Minho.

Pan, Y., Wei, G., Cunningham, A.A., Li, S., Chen, S., Milner-Gulland, E.J., Turvey, S.T., 2016. Using local ecological knowledge to assess the status of the critically endangered Chinese giant salamander Andrias davidianus in Guizhou Province, China. Oryx 50, 257-264.

Pauly, D., 1995. Anecdotes and the shifting baseline syndrome of fisheries. Trends in Ecology and Evolution 10, 430.

Popejoy, T., Randklev, C.R., Neeson, T.M., Vaughn, C.C., 2018a. Prioritizing sites for conservation based on similarity to historical baselines and feasibility of protection. Conserv. Biol. 32, 1118-1127.

Popejoy, T., Randklev, C.R., Wolverton, S., Nagaoka, L., 2018b. Conservation implications of late Holocene freshwater mussel remains of the Leon River in central Texas. Hydrobiologia 810, 477-487.

Preston, S.J., Keys, A., Roberts, D., 2007. Culturing freshwater pearl mussel Margaritifera margaritifera: a breakthrough in the conservation of an endangered species. Aquat. Conserv. Mar. Freshwat. Ecosyst. 17, 539-549.

Reis, J., 2003. The freshwater pearl mussel [Margaritifera margaritifera (L.)](Bivalvia, Unionoida) rediscovered in Portugal and threats to its survival. Biol. Conserv. 114, 447-452.

Rubin, H.J., Rubin, I.S., 2005. Qualitative Interviewing: The Art of Hearing Data. Sage, London, UK, p. 283.

Soga, M., Gaston, K.J., 2016. Extinction of experience: the loss of human-nature interactions. Front. Ecol. Environ. 14, 94-101.

Soga, M., Gaston, K.J., 2018. Shifting baseline syndrome: causes, consequences, and implications. Front. Ecol. Environ. 16, 222-230.

Sousa, R., Amorim, Â., Froufe, E., Varandas, S., Teixeira, A., Lopes-Lima, M., 2015. Conservation status of the freshwater pearl mussel Margaritifera margaritifera in Portugal. Limnologica 50, 4-10.

Sousa, R., Ferreira, A., Carvalho, F., Lopes-Lima, M., Varandas, S., Teixeira, A., Gallardo, B., 2020. Small hydropower plants as a threat to the endangered pearl mussel Margaritifera margaritifera. Sci. Total Environ. 719, 137361.

Tachet, H., Richoux, P., Bournaud, M., Usseglio-Polatera, P., 2003. Invertébrés d'eau douce: systématique, biologie, écologie. 15. CNRS éditions, Paris.

Turvey, S.T., Barret, L.A., Yujiang, H., Lei, Z., Xinqiao, Z., Xinyan, W., Yadong, H., Kaiya, Z., Hart, T., Ding, W., 2010. Rapidly shifting baselines in Yangtze fishing communities and local memory of extinct species. Conserv. Biol. 3, 778-787.

Turvey, S.T., Fernández-Secades, C., Nuñez-Miño, J.M., Hart, T., Martinez, P., Brocca, J.L., Young, R.P., 2014. Is local ecological knowledge a useful conservation tool for small mammals in a Caribbean multicultural landscape? Biol. Conserv. 169, 189-197.

Van, T.P., Le Duc, O., Leprince, B., Bordes, C., Luu, V.Q., Luiselli, L., 2020. Hunters' structured questionnaires enhance ecological knowledge and provide circumstantial survival evidence for the world's rarest turtle. Aquat. Conserv. Mar. Freshwat. Ecosyst. 30 183-193.

Varandas, S., Lopes-Lima, M., Teixeira, A., Hinzmann, M., Reis, J., Cortes, R., Machado, J., Sousa, R., 2013. Ecology of southern European pearl mussels (Margaritifera margaritifera): first record of two new populations on the rivers Terva and Beça (Portugal). Aquat. Conserv. Mar. Freshwat. Ecosyst. 23, 374-389.

White, P.C., Jennings, N.V., Renwick, A.R., Barker, N.H., 2005. Questionnaires in ecology: a review of past use and recommendations for best practice. J. Appl. Ecol. 42, 421-430.

Zając, K., Florek, J., Zając, T., Adamski, P., Bielański, W., Ćmiel, A.M., Klich, M., Lipińska, A.M., 2018. On the reintroduction of the endangered thick-shelled river musse Unio crassus: the importance of the river's longitudinal profile. Sci. Total Environ. 624, 273-282.

Ziembicki, M.R., Woinarski, J.C.Z., Mackey, B., 2013. Evaluating the status of species using indigenous knowledge: novel evidence for major native mammal declines in northern Australia. Biol. Conserv. 157, 78-92. 